\title{
Comparison Between Xanthomonas campestris pv. manihotis (ISPP List 1980) and $X$. campestris pv. cassavae (ISPP List 1980) by Means of Phenotypic, Protein Electrophoretic, DNA Hybridization and Phytopathological Techniques
}

\author{
By M. VAN DEN MOOTER, ${ }^{1}$ H. MARAITE, ${ }^{2}$ L. MEIRESONNE, ${ }^{1}$ \\ J. SWINGS,$^{1}$ M. GILLIS, ${ }^{1} K$. KERSTERS ${ }^{1}$ AND J. DE LEY ${ }^{1 *}$ \\ ${ }^{1}$ Laboratorium voor Microbiologie en microbiële Genetica, Rijksuniversiteit, Ledeganckstraat 35 , \\ B-9000 Gent, Belgium \\ ${ }^{2}$ Laboratoire de Phytopathologie, Université Catholique de Louvain, Place Croix du Sud 3, \\ B-1348 Louvain-la-Neuve, Belgium
}

(Received I April 1986; revised I6 June 1986)

\begin{abstract}
Xanthomonas campestris pv. manihotis (ISPP List 1980) and X. campestris pv. cassavae (ISPP List 1980) strains, isolated from cassava (Manihot esculenta) plants of different geographical origin, were studied by numerical analysis of 267 phenotypic features, computer-assisted comparison of gel electrophoregrams of soluble proteins, $\mathrm{mol} \% \mathrm{G}+\mathrm{C}$ determinations, DNA:DNA hybridizations and virulence tests. $X$. campestris pv. manihotis and pv. cassavae constituted separate biological entities which could be differentiated from each other by four biochemical features, their symptoms on cassava, their soluble protein electrophoregrams and their DNA characteristics. Within each pathovar no correlation was found between phytopathogenicity, geographic origin and year of isolation of the strains, on the one hand, and the biochemical, physiological and protein electrophoretic properties on the other. Two yellowish Xanthomonas strains, CIAT 1164 and CIAT 1165, isolated from cassava in Colombia were genetically and electrophoretically similar to $X$. campestris pv. poinsettiicola, but were unable to infect Euphorbia pulcherrima. $X$. campestris pv. poinsettiicola was genetically more related to the $X$. campestris $\mathrm{pv}$. manihotis cluster than to the $X$. campestris pv. cassavae cluster.
\end{abstract}

\section{INTRODUCTION}

Two pathovars of Xanthomonas campestris (Pammel 1958) Dowson 1939 have been recorded on cassava (Manihot esculenta Crantz). The white $X$. campestris pv. manihotis (ISPP List 1980: see Dye et al., 1980) originated from South America but now has a worldwide distribution (Maraite et al., 1981). It causes the severe cassava bacterial blight disease characterized by angular spots extending into blight areas on the leaves and a systemic infection of the stem, leading to wilt and die-back. The yellow $X$. campestris pv. cassavae (ISPP List 1980: see Dye et al., 1980) is at present restricted to the East African highlands. It causes cassava bacterial necrosis disease, which is generally much less severe than the cassava bacterial blight disease. Cassava bacterial necrosis is characterized by angular leaf spots and a cortical infection of the stem; but, leaf blight or systemic invasion of the plant do not occur.

Robbs et al. (1972) isolated in Brazil a pv. manihotis strain, with reduced virulence, that caused symptoms similar to those induced by pv. cassavae; they suggested that pv. cassavae might be considered as a synonym of pv. manihotis, and simply referred to it as a yellow variant of the latter taxon. In other studies, comprising physiological, biochemical and inoculation tests (Maraite \& Weyns, 1979; Maraite \& Perreaux, 1979), the strain used by Robbs et al. (1972), which is the neopathotype strain of pv. manihotis (Bradbury, 1984), behaved in a similar fashion to other strains of pv. manihotis and was clearly different from pv. cassavae strains. 
Sabet et al. (1969) reported an overlap in the host-range among isolates from Euphorbiaceae: an isolate from Euphorbia pulcherrima also infected $\boldsymbol{M}$. esculenta, and an isolate from the common weed Euphorbia acalyphoides also infected Ricinus communis and E. pulcherrima, but not M. esculenta.

The present study was undertaken in order to clarify the relationships between the various xanthomonads occurring on cassava, using a numerical analysis of 267 phenotypic features, gel electrophoresis of soluble cellular proteins, $\mathrm{mol} \% \mathrm{G}+\mathrm{C}$ determinations, DNA:DNA hybridizations and phytopathological tests.

\section{METHODS}

Organisms used. The strains studied are listed in Table 1. They were grown at $28^{\circ} \mathrm{C}$ on GYCA medium (modified from Dye, 1962), containing 1\%(w/v) D-glucose, $0.5 \%(\mathrm{w} / \mathrm{v})$ yeast extract (Oxoid), $3 \%(\mathrm{w} / \mathrm{v}) \mathrm{CaCO}_{3}$ and $2 \%(\mathrm{w} / \mathrm{v})$ agar in tap water, or on GYEA medium, containing $0.5 \%(\mathrm{w} / \mathrm{v}) \mathrm{D}$-glucose, $0.1 \%(\mathrm{w} / \mathrm{v})$ yeast extract (Oxoid), $0.0001 \%(\mathrm{w} / \mathrm{v}) \mathrm{FePO}_{4}$ and $2 \%(\mathrm{w} / \mathrm{v})$ agar. The isolates were maintained at $4{ }^{\circ} \mathrm{C}$ on GYCA medium and transferred monthly.

Phenotypic features tested. A total of 267 phenotypic features were examined. Liquid media were inoculated with two drops of a suspension containing approximately $7 \times 10^{8}$ cells per $\mathrm{ml}$ distilled water and incubated with shaking, unless stated otherwise. Solid media in Petri dishes were inoculated with a multipoint inoculator, and incubated at $28^{\circ} \mathrm{C}$ for $7 \mathrm{~d}$, unless stated otherwise. The colony morphology (diameter, profile, slime production, pigmentation, growth rate and formation of a brown water-soluble pigment) was examined for $9 \mathrm{~d}$ on GYCA medium (Dye, 1962). Cell morphology was examined on 24- to 48-h-old GYCA grown-cells. Gram-staining was done according to Hucker's method (Doetsch, 1981). Formation of a fluorescent pigment and growth on Pseudomonas-F agar (Oxoid) were tested. Acetoin production was examined after $5 \mathrm{~d}$ in YS medium (Dye, 1962) supplemented with 0.5\% (w/v) D-glucose, by using Barritt's reagent (Barritt, 1936). Indole production was tested after $5 \mathrm{~d}$ in a medium containing $0.5 \%(\mathrm{w} / \mathrm{v})$ yeast extract and $2 \%(\mathrm{w} / \mathrm{v})$ tryptone (Oxoid) using Kovacs' reagent (Kovac, 1928). The production of $\mathrm{H}_{2} \mathrm{~S}$ from L-cysteine was examined in a medium containing $0.05 \%(\mathrm{w} / \mathrm{v})$ $\mathrm{NH}_{4} \mathrm{H}_{2} \mathrm{PO}_{4}, 0.05 \%(\mathrm{w} / \mathrm{v}) \mathrm{K}_{2} \mathrm{HPO}_{4}, 0.02 \%(\mathrm{w} / \mathrm{v}) \mathrm{MgSO}_{4} .7 \mathrm{H}_{2} \mathrm{O}, 0.5 \%(\mathrm{w} / \mathrm{v})$ yeast extract to which L-cysteine (autoclaved separately for $10 \mathrm{~min}$ ) was added to give a final concentration of $0.02 \%(\mathrm{w} / \mathrm{v}) . \mathrm{H}_{2} \mathrm{~S}$ production was detected by the blackening of lead acetate paper strips (tubes were not shaken).

Nitrate reduction was tested after $5 \mathrm{~d}$ in a medium containing $0.05 \%(\mathrm{w} / \mathrm{v}) \mathrm{KH}_{2} \mathrm{PO}_{4}, 0.05 \%(\mathrm{w} / \mathrm{v}) \mathrm{K}_{2} \mathrm{HPO}_{4}$, $0.02 \%(\mathrm{w} / \mathrm{v}) \mathrm{MgSO}_{4} .7 \mathrm{H}_{2} \mathrm{O}, 0.2 \%(\mathrm{w} / \mathrm{v})$ sodium succinate, $0.3 \%(\mathrm{w} / \mathrm{v}) \mathrm{KNO}_{3}$ and $0.5 \%(\mathrm{w} / \mathrm{v})$ yeast extract. Catalase was tested by suspending a loopful of cells in $10 \%(\mathrm{v} / \mathrm{v}) \mathrm{H}_{2} \mathrm{O}_{2}$. Oxidase was tested by Kovacs' procedure (Kovac, 1956). Gelatinase was detected with charcoal gelatin discs (Oxoid) in a liquid medium containing $0.5 \%$ $(\mathrm{w} / \mathrm{v})$ yeast extract, $0.5 \%(\mathrm{w} / \mathrm{v})$ neutralized peptone (Oxoid) and $0.5 \%(\mathrm{w} / \mathrm{v}) \mathrm{D}$-glucose. Urease activity was tested according to Dye (1962). Starch hydrolysis was tested on a medium containing $0.5 \%(\mathrm{w} / \mathrm{v})$ yeast extract, $0.5 \%(\mathrm{w} / \mathrm{v})$ neutralized peptone, $0.3 \%(\mathrm{w} / \mathrm{v})$ soluble starch and $2 \%(\mathrm{w} / \mathrm{v})$ agar in distilled water. The Petri dishes were heavily inoculated with a loopful of cells, and after $2 \mathrm{~d}$ incubation, Lugol's iodine solution was poured on the plates. Aesculin hydrolysis was tested by heavily inoculating GYEA medium to which $0.3 \%$ (w/v) aesculin and $0.05 \%$ $(w / v)$ ferric ammonium citrate had been added. Hydrolysis of Tween 80 and Tween 60 was observed on a medium consisting of $1 \%(\mathrm{w} / \mathrm{v})$ peptone (Oxoid), $0.01 \%(\mathrm{w} / \mathrm{v}) \mathrm{CaCl}_{2} .2 \mathrm{H}_{2} \mathrm{O}, 0 \cdot 1 \%(\mathrm{w} / \mathrm{v})$ yeast extract, $2 \%(\mathrm{w} / \mathrm{v})$ agar and $1 \%(\mathrm{v} / \mathrm{v})$ Tween. The Tweens were sterilized and added separately. Lecithinase activity was checked on GYEA medium supplemented with $11 \%(\mathrm{v} / \mathrm{v})$ egg yolk emulsion (Oxoid). All media were heavily inoculated with a loopful of cells. $\beta$-Glucosidase was tested in a medium containing $0.05 \%(w / v) \mathrm{K}_{2} \mathrm{HPO}_{4}, 0.05 \%(w / v) \mathrm{NH}_{4} \mathrm{H}_{2} \mathrm{PO}_{4}$, $0.02 \%(\mathrm{w} / \mathrm{v}) \mathrm{MgSO}_{4} .7 \mathrm{H}_{2} \mathrm{O}, 0.1 \%(\mathrm{w} / \mathrm{v})$ yeast extract and $0.7 \mathrm{ml}$ of a $1.5 \%(\mathrm{w} / \mathrm{v})$ bromcresol purple solution in ethanol to which filter-sterilized arbutin was added to a final concentration of $1 \%(w / v)$. To detect polygalacturonase a modified Paton's medium (Paton, 1959) was used, consisting of two layers: layer A containing $0.5 \%(\mathrm{w} / \mathrm{v})$ yeast extract, $0.5 \%(\mathrm{w} / \mathrm{v})$ neutralized peptone, $0.5 \%(\mathrm{w} / \mathrm{v})$ calcium lactate, $0.5 \%(\mathrm{w} / \mathrm{v})$ D-glucose and $2 \%$ $(\mathrm{w} / \mathrm{v})$ agar; and layer B containing $2 \%(\mathrm{w} / \mathrm{v})$ sodium polygalacturonate and $0.1 \%(\mathrm{w} / \mathrm{v})$ disodium ethylenediaminetetra-acetate. Enzymic activity was observed after $5 \mathrm{~d}$. DNAase activity was tested on DNase agar (Oxoid) by pouring $1 \mathrm{M}-\mathrm{HCl}$ on the plates. Clear zones around the cultures indicated DNAase activity. The action in litmus milk was observed for $18 \mathrm{~d}$. The medium contained $10 \%(\mathrm{w} / \mathrm{v})$ skim milk powder (Oxoid) and $0.07 \%(\mathrm{w} / \mathrm{v})$ soluble litmus. It was autoclaved for $10 \mathrm{~min}$ and was not shaken. The $\mathrm{O} / \mathrm{F}$ (oxidation/fermentation) test was done by stab-inoculation in a medium containing $0.01 \%(\mathrm{w} / \mathrm{v})$ yeast extract, $0.1 \%(\mathrm{w} / \mathrm{v}) \mathrm{NH}_{4} \mathrm{H}_{2} \mathrm{PO}_{4}$, $0.02 \%(\mathrm{w} / \mathrm{v}) \mathrm{MgSO}_{4} .7 \mathrm{H}_{2} \mathrm{O}, 0.02 \%(\mathrm{w} / \mathrm{v}) \mathrm{KCl}, 0.3 \%(\mathrm{w} / \mathrm{v})$ agar, $0.003 \%(\mathrm{w} / \mathrm{v})$ bromthymol blue and $1 \%(\mathrm{w} / \mathrm{v}) \mathrm{D}-$ glucose (sterilized separately). Reactions were observed daily for 2 weeks. Acid formation from carbohydrates was detected after $9 \mathrm{~d}$ in a basal medium (Dye, 1962) containing the following filter-sterilized carbohydrates at a final concentration of $1 \%(\mathrm{w} / \mathrm{v})$ : L-arabinose, cellobiose, D-fructose, D-galactose, maltose, D-mannose, D-ribose, sucrose, D-xylose, salicin, meso-erythritol, raffinose, melibiose, trehalose, L-rhamnose, lactose, D-glucose, sorbitol, 
adonitol, L-sorbose, dulcitol, amygdalin and meso-inositol. Utilization of carbon sources was tested using the basal medium of Starr (1945). The following carbon sources were sterilized separately by filtration and were tested at a final concentration of $0.2 \%(w / v)$, unless stated otherwise: L-rhamnose $(0 \cdot 18 \%)$, sodium 2-ketogluconate, salicin, inulin, glycolic acid, L-leucine $(0.1 \%)$, L-threonine $(0.1 \%)$, glycine $(0.1 \%)$, L-tryptophan $(0.1 \%)$, L-lysine $(0.08 \%)$, L-cysteine $(0.1 \%)$, L-arginine $(0.1 \%)$, L-methionine $(0.1 \%)$, L-isoleucine $(0.1 \%)$, ethanolamine $(0.1 \%)$, sodium hippurate $(0.09 \%)$, acetamide $(0.1 \%)$, n-butyrate $(0.1 \%)$, DL- $\beta$-hydroxybutyrate $(0.1 \%)$, pelargonate $(0.1 \%)$, ethanol $(0 \cdot 1 \%)$, n-butanol $(0 \cdot 1 \%)$, iso-butanol $(0 \cdot 1 \%)$, diethyleneglycol $(0 \cdot 1 \%)$, adonitol, D-glucose, D-mannose, trehalose, cellobiose, D-fructose, D-galactose, maltose $(0 \cdot 19 \%)$, melibiose $(0 \cdot 19 \%)$, sucrose, glycerol, D-alanine $(0.1 \%)$, L-alanine $(0.1 \%)$, L-glutamic acid $(0.1 \%)$, saccharic acid, mucic acid and DL-glyceric acid. All stock solutions of carbon sources, except sugars, were adjusted to $\mathrm{pH} 7.0$ by addition of $1 \mathrm{M}-\mathrm{NaOH}$ or $1 \mathrm{~m}-\mathrm{HCl}$. Growth on some organic acids was tested using a basal medium containing $0.005 \%(w / v)$ yeast extract, $0.01 \%(w / v)$ vitamin-free Casamino acids, $0.05 \%(\mathrm{w} / \mathrm{v}) \mathrm{NH}_{4} \mathrm{H}_{2} \mathrm{PO}_{4}, 0.05 \%(\mathrm{w} / \mathrm{v}) \mathrm{K}_{2} \mathrm{HPO}_{4}, 0.02 \%(\mathrm{w} / \mathrm{v}) \mathrm{MgSO}_{4} .7 \mathrm{H}_{2} \mathrm{O}$, $0.0016 \%(w / v)$ bromthymol blue and $2 \%(w / v)$ agar (final pH 6.8). The organic acids (pH adjusted with $1 \mathrm{M}-\mathrm{NaOH}$ to $\mathrm{pH} 6.8)$ were sterilized by filtration and added to a final concentration of $0.2 \%(\mathrm{w} / \mathrm{v})$. The following organic salts were tested: sodium acetate, sodium malate, trisodium citrate, calcium D-gluconate, potassium-sodium tartrate, sodium fumarate, calcium lactate, sodium benzoate, sodium oxalate, sodium succinate and sodium propionate. The requirement for organic nitrogen and/or growth factors was determined by testing growth on the following media: (i) $0.1 \%(w / v) \mathrm{NH}_{4} \mathrm{Cl}$ and $1 \%$ (w/v) D-glucose; (ii) $0.1 \%(\mathrm{w} / \mathrm{v}) \mathrm{NH}_{4} \mathrm{Cl}, 1 \%(\mathrm{w} / \mathrm{v}) \mathrm{D}$-glucose, $1.6 \%(\mathrm{v} / \mathrm{v})$ mineral solution $\mathrm{A}\left[6 \%(\mathrm{w} / \mathrm{v}) \mathrm{KH}_{2} \mathrm{PO}_{4}\right.$ and $\left.1.2 \%(\mathrm{w} / \mathrm{v}) \mathrm{MgSO}_{4} .7 \mathrm{H}_{2} \mathrm{O}, \mathrm{pH} \mathrm{6.8}\right]$ and $0.5 \%(\mathrm{v} / \mathrm{v})$ mineral solution $\mathrm{B}$ $\left[0.0001 \%(\mathrm{w} / \mathrm{v}) \mathrm{H}_{3} \mathrm{BO}_{3}, 0.002 \%(\mathrm{w} / \mathrm{v}) \mathrm{CaCO}_{3}, 0.0002 \%(\mathrm{w} / \mathrm{v}) \mathrm{CuSO}_{4} .5 \mathrm{H}_{2} \mathrm{O}, 0.00002 \%(\mathrm{w} / \mathrm{v}) \mathrm{KI}, 0.0002 \%(\mathrm{w} / \mathrm{v})\right.$ $\mathrm{MnSO}_{4} \cdot \mathrm{H}_{2} \mathrm{O}, 0.0002 \%(\mathrm{w} / \mathrm{v}) \mathrm{MoO}_{3}$ and $0.0032 \%(\mathrm{w} / \mathrm{v}) \mathrm{ZnSO}_{4} \cdot 7 \mathrm{H}_{2} \mathrm{O}$ ]; (iii) medium (ii) plus $5 \%$ (v/v) vitamin solution $[0.0015 \%(w / v)$ thiamin, $0.0015 \%(w / v)$ riboflavin, $0.001 \%(w / v)$ calcium $D$-panthothenate, $0.00001 \%$ $(\mathrm{w} / \mathrm{v})$ biotin, $0.001 \%(\mathrm{w} / \mathrm{v})$ pyridoxal hydrochloride, $0.001 \%(\mathrm{w} / \mathrm{v})$ p-aminobenzoic acid, $0.001 \%(\mathrm{w} / \mathrm{v}) \mathrm{vitamin}$ B12, $0.001 \%(w / v)$ folic acid and $0.005 \%(w / v)$ nicotinic acid in distilled water]; (iv) medium (ii) plus $5 \%$ (v/v) vitamin solution and $0.3 \%(\mathrm{w} / \mathrm{v})$ vitamin-free Casamino acids; (v) medium (iv) from which $\mathrm{NH}_{4} \mathrm{Cl}$ was omitted. Growth on $0.2 \%(\mathrm{w} / \mathrm{v})$ vitamin-free Casamino acids, $0.5 \%(\mathrm{w} / \mathrm{v})$ peptone or $0.5 \%(\mathrm{w} / \mathrm{v})$ yeast extract was also verified. The utilization of 22 single L-amino acids as sole nitrogen source was tested in a basal medium containing $1 \%(\mathrm{w} / \mathrm{v})$ D-glucose, $1.6 \%(\mathrm{v} / \mathrm{v})$ mineral solution A, $0.5 \%(\mathrm{v} / \mathrm{v})$ mineral solution $\mathrm{B}$ and $5 \%(\mathrm{v} / \mathrm{v})$ of the filtersterilized vitamin solution. The amino acids were sterilized separately and added to the basal medium to a final concentration of $0 \cdot 1 \%(w / v)$. The utilization of L-alanine, glycine, L-glutamine, L-glutamic acid, L-asparagine, Lhydroxyproline and L-proline as sole source of carbon and nitrogen was tested in the same basal medium from which D-glucose was omitted. The stimulatory effect of low concentrations $(0 \cdot 02 \%, \mathrm{w} / \mathrm{v})$ of single $\mathrm{L}$-amino acids on the growth was verified on a basal medium containing $0.1 \%(\mathrm{w} / \mathrm{v}) \mathrm{NH}_{4} \mathrm{Cl}, 1 \%(\mathrm{w} / \mathrm{v}) \mathrm{D}-\mathrm{glucose}, 1 \cdot 6 \%(\mathrm{v} / \mathrm{v})$ mineral solution $\mathrm{A}, 0.5 \%(\mathrm{v} / \mathrm{v})$ mineral solution $\mathrm{B}$ and $5 \%(\mathrm{v} / \mathrm{v})$ vitamin solution to which the L-amino acid was added.

Growth was tested after $8 \mathrm{~d}$ on a methionine/glutamic acid (MG) medium containing $0.5 \%(\mathrm{w} / \mathrm{v}) \mathrm{D}$-glucose, $1.6 \%(\mathrm{v} / \mathrm{v})$ mineral solution $\mathrm{A}, 0.5 \%(\mathrm{v} / \mathrm{v})$ mineral solution $\mathrm{B}, 5 \%(\mathrm{v} / \mathrm{v})$ vitamin solution, $0.2 \%(\mathrm{w} / \mathrm{v}) \mathrm{L}$-methionine, $0.2 \%(w / v)$ L-glutamic acid and $2 \%(w / v)$ agar. Growth on SX agar (Schaad, 1980) was checked after $10 \mathrm{~d}$. Anaerobic growth was tested on GYEA medium in an anaerobic jar. Growth in the presence of 10 and $20 \%(w / v)$ D-glucose was observed in GYEA medium. Concentrated D-glucose solution was autoclaved separately for $10 \mathrm{~min}$. The tolerance towards filter-sterilized dyes and metals was tested in GYEA medium. The tolerance towards triphenyltetrazolium chloride $(0.005,0.01,0.05$ and $0.1 \%$, w/v) or $0.1 \%(w / v)$ Actidione was tested in GYEA medium. Growth at different temperatures $\left(4,28,37^{\circ} \mathrm{C}\right)$, the ability to grow at initial pH values of $4 \cdot 5,5 \cdot 5,6 \cdot 5,7 \cdot 5$ and 8.5 , and the tolerance towards $1,2,3$ and $4 \%(w / v) ~ N a C l$ was tested on GYEA medium. The in vitro susceptibility towards 20 antibiotics was determined by the Kirby-Bauer technique (Bauer et al., 1966) using Oxoid sensitivity discs. The basal medium was YPGA $[0.5 \%(\mathrm{w} / \mathrm{v})$ yeast extract, $0.5 \%(\mathrm{w} / \mathrm{v})$ neutralized peptone, $0.5 \%(\mathrm{w} / \mathrm{v}) \mathrm{D}$-glucose and $2.5 \%(\mathrm{w} / \mathrm{v})$ Oxoid no. $1 \mathrm{agar}$. Inhibition zones were recorded after 36 to $48 \mathrm{~h}$; diameters of $12 \mathrm{~mm}$ or more were interpreted as susceptible. The following antibiotics were tested: $10 \mu \mathrm{g}$ ampicillin, $10 \mathrm{U}$ bacitracin, $25 \mu \mathrm{g}$ cephaloridin, $30 \mu \mathrm{g}$ chloramphenicol, $10 \mu \mathrm{g}$ colistin sulphate, $10 \mu \mathrm{g}$ erythromycin, $10 \mu \mathrm{g}$ fucidic acid, $10 \mu \mathrm{g}$ gentamycin, $2 \mu \mathrm{g}$ lincomycin, $30 \mu \mathrm{g}$ kanamycin, $10 \mu \mathrm{g}$ methicillin, $200 \mu \mathrm{g}$ nitrofurantoin, $30 \mu \mathrm{g}$ neomycin, $30 \mu \mathrm{g}$ nalidixic acid, $30 \mu \mathrm{g}$ novobiocin, $10 \mathrm{U}$ penicillin $\mathrm{G}, 300 \mathrm{U}$ polymyxin, $10 \mu \mathrm{g}$ streptomycin, $100 \mu \mathrm{g}$ sulfafurazole and $30 \mu \mathrm{g}$ tetracycline.

Numerical analysis of phenotypic features. All 267 features were coded as 2 (positive) or 1 (negative). Missing features were coded as 0 (no comparison). Similarities between the strains were calculated with the similarity coefficient $S_{S M}$ of Sokal \& Michener (1958) using a modified program of Bonham-Carter (1967). The clustering of the strains was done according to the unweighted average pair-group method (Sneath \& Sokal, 1973) with the Clustan 1C program (Wishart, 1978) using the Siemens 7551 (BS2000) computer of the Centraal Digitaal Rekencentrum, Rijksuniversiteit, Gent, Belgium.

Numerical analysis of protein gel electrophoregrams. The preparation of the soluble protein fractions, PAGE and 


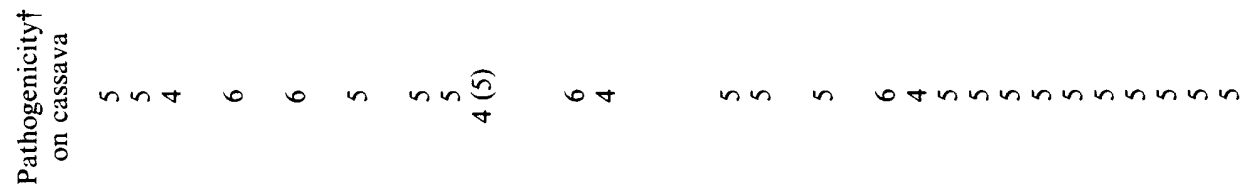
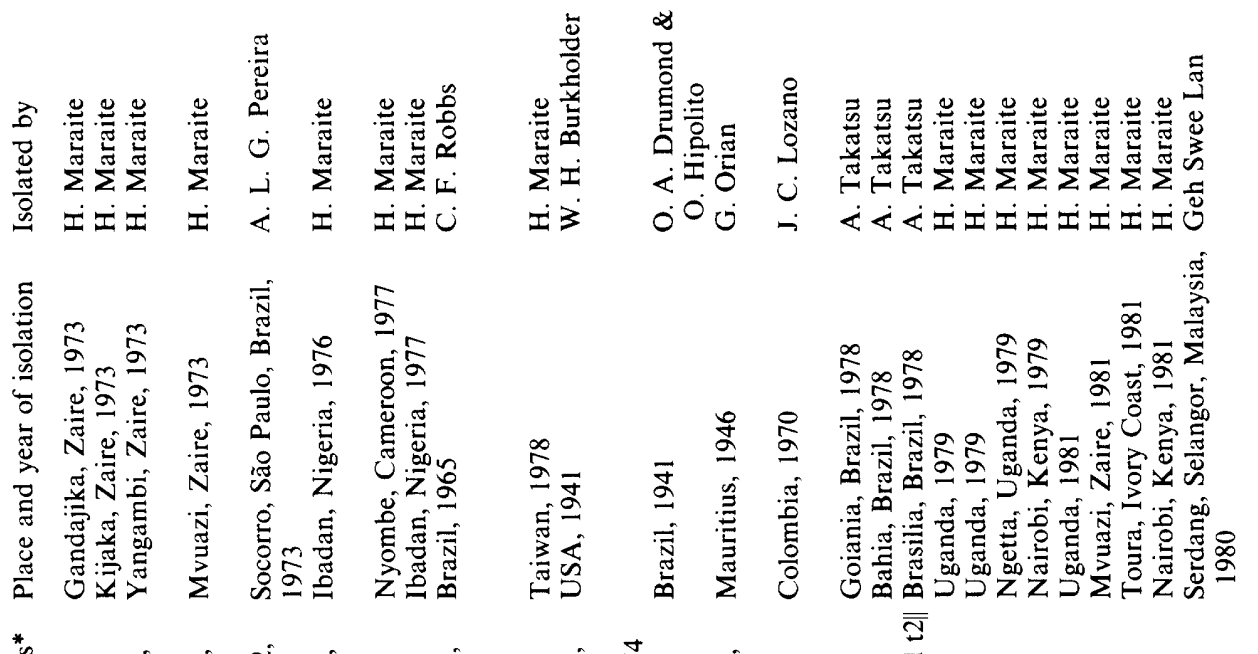

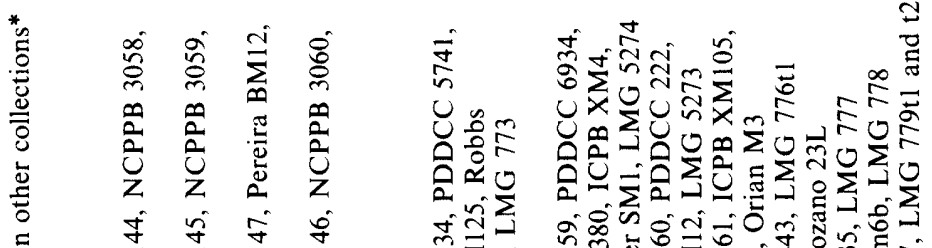

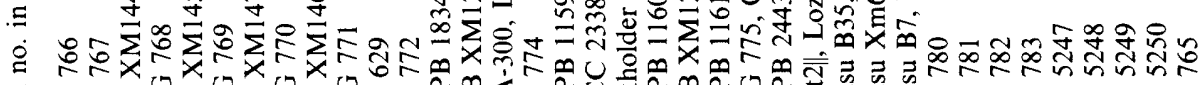

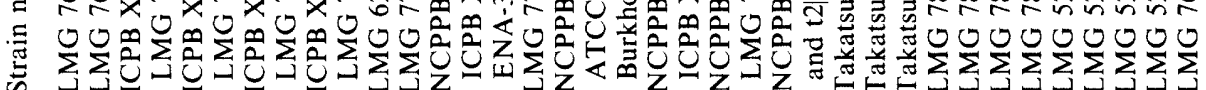

$\stackrel{\dot{0}}{\frac{0}{\circ}}$

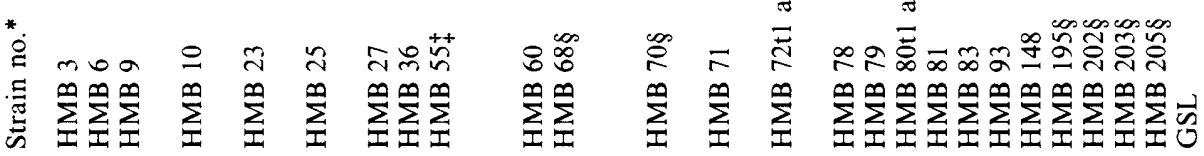

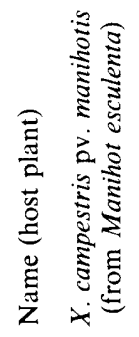




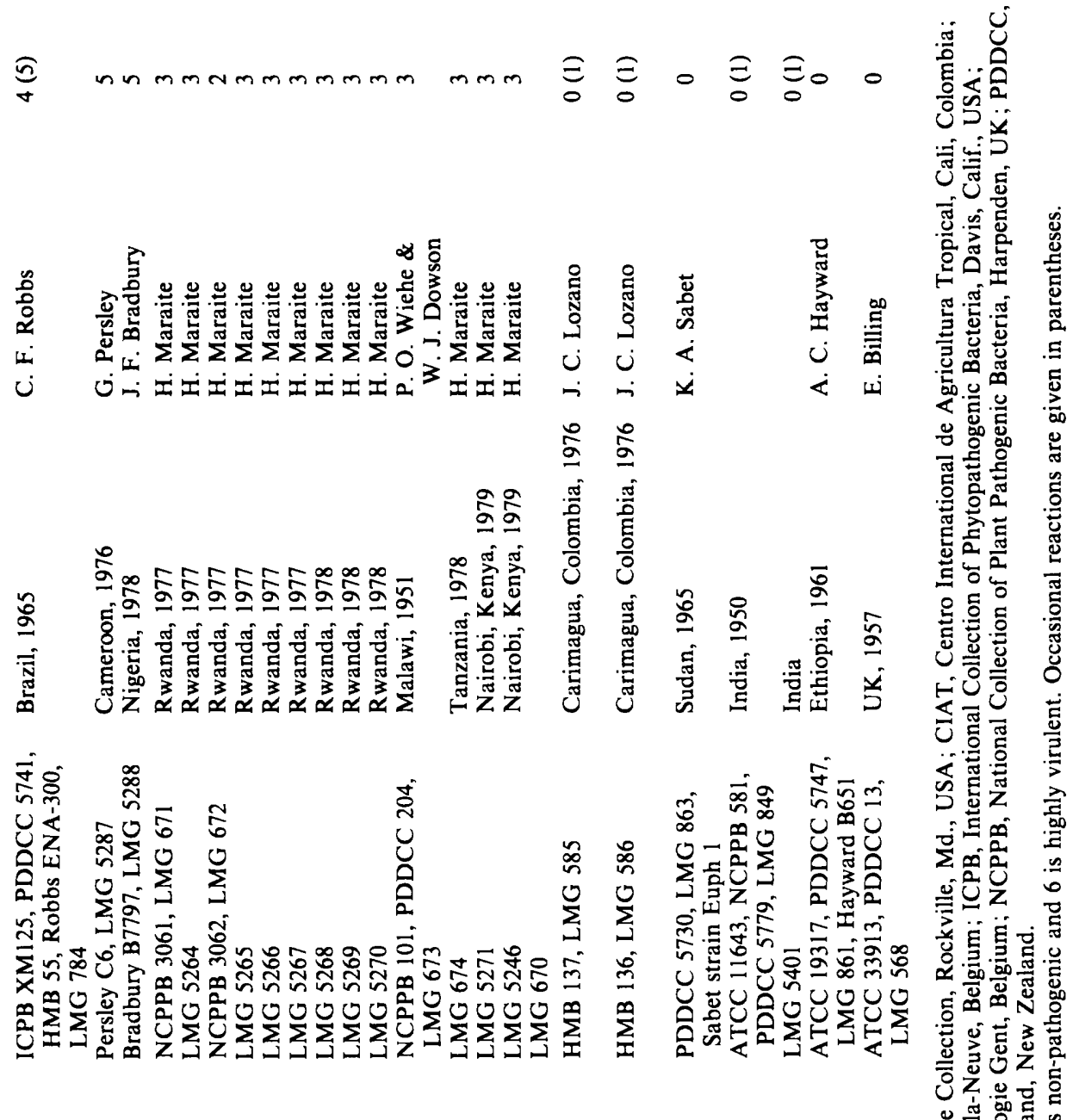

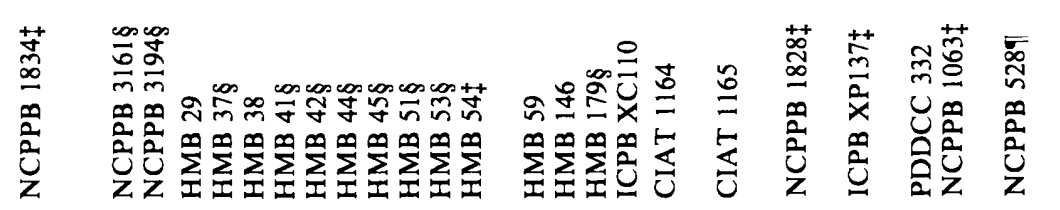

놀응

离密

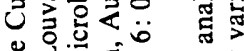

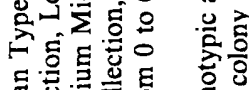

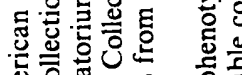

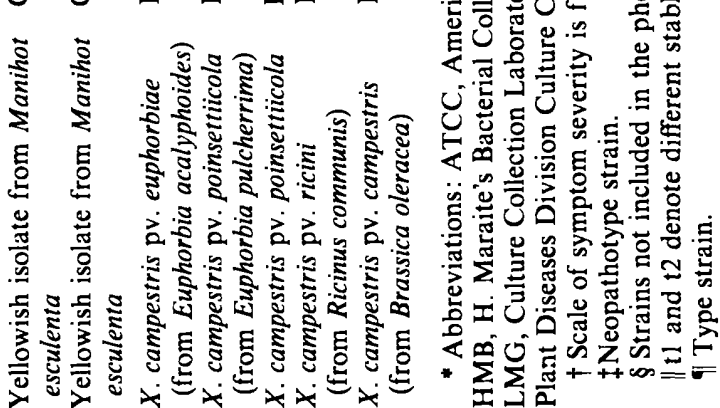


computer-assisted comparisons of normalized protein electrophoregrams were done as previously described (Kersters \& De Ley, 1975; Vera Cruz et al., 1984).

DNA base composition. DNA was prepared according to the method of Marmur (1961). The mean mol \% $\mathrm{G}+\mathrm{C}$ content of the overall genome DNA of representative Xanthomonas strains was determined by the thermal denaturation method (De Ley \& Van Muylem, 1963) and calculated by the equation of Marmur \& Doty (1962) as modified by De Ley (1970).

DNA : DNA hybridizations. The degree of DNA-binding $(\% D)$ was determined spectrophotometrically from the initial renaturation rates using the method of De Ley et al. (1970). Renaturations were done in $2 \times \operatorname{SSC}(1 \times$ SSC is $0.15 \mathrm{M}-\mathrm{NaCl}, 0.015 \mathrm{M}$-trisodium citrate, $\mathrm{pH} 7.0)$ at optimal renaturation temperature $\left(81^{\circ} \mathrm{C}\right)$ with a DNA concentration of approximately $60 \mu \mathrm{g} \mathrm{m}^{-1}$. We used a Gifford 2600 spectrophotometer equipped with a thermostatted cuvette chamber and a Hewlett-Packard 7225A plotter.

Phytopathogenicity tests. Pathogenicity of all strains was tested on cassava plants, cultivar Eala Amer 07, multiplied from cuttings provided by the Institut des Sciences Agronomiques du Rwanda, Rubona, Rwanda. Selected strains were also inoculated in Euphorbia pulcherrima plants purchased in Belgium as ornamental plants (without cultivar specification) and in Ricinus communis plants (without cultivar specification) grown from seeds provided by the Unité de Phytotechnie tropicale, Université Catholique de Louvain. The plants were grown and the leaf and stem inoculations done according to previously described methods (Maraite et al., 1981).

The evolution of the symptoms was assessed during 6 weeks and the observed reactions rated according to the following scale: 0 , no reaction on leaf or stem inoculation; 1 , small water-soaked area extending less than $1 \mathrm{~mm}$ around the inoculation point and becoming necrotic within 1 week; 2 , water-soaked angular spots (on the leaves) larger than $1 \mathrm{~mm}$ and extending during incubation; 3 , formation on the leaves of secondary spots along the veins and of dark areas on the stem extending more than $5 \mathrm{~mm}$ from the inoculation point; 4 , formation of blighted areas on the lamina after 2 weeks and slow systemic infection of the stem leading to the formation of exudates and wilt that often stopped after 3 weeks; 5 , appearance of the blight symptoms between 9 and $12 \mathrm{~d}$ after inoculation, and regular systemic infection of the stem leading generally to wilt of the apical part within 1 month; 6 , appearance of blight symptoms $7 \mathrm{~d}$ after leaf inoculation and fast stem infection leading to tip die-back within 3 weeks.

\section{RESULTS}

\section{Numerical analysis of phenotypic features}

Twenty-three $X$. campestris pv. manihotis strains, six $X$. campestris pv. cassavae strains, the type strain of the type species $X$. campestris (NCPPB 528), and three $X$. campestris strains isolated from other Euphorbiaceae ( $X$. campestris pv. poinsettiicola ICPB XP137, X. campestris pv. euphorbiae NCPPB 1828 and $X$. campestris pv. ricini NCPPB 1063) were examined for 267 phenotypic features. The $S_{S M}$ values between the replicates of three duplicated strains had a mean $( \pm S D)$ of $96.4 \pm 1.6 \%$. The dendrogram of the numerical analysis using the $S_{S M}$ coefficient and the unweighted average pair group method is shown in Fig. 1. The $23 X$. campestris pv. manihotis strains clustered together in phenon 1 at $80 \% S_{S M}$. Phenon 2 contained five $X$. campestris pv. cassavae strains at the $83 \% S_{S M}$ level. The type strain of $X$. campestris and the neopathotype strains of $X$. campestris pv. euphorbiae, pv. poinsettiicola and pv. ricini grouped together at $83 \% S_{S M}$. X. campestris pv. cassavae strain HMB 38 occupied a separate position in the dendrogram.

\section{Morphological, physiological and biochemical features}

The following features occurred in all 33 strains examined: the cells were Gram-negative motile rods, occurring singly, measuring 0.3 to $0.5 \mu \mathrm{m}$ by 1.3 to $2.1 \mu \mathrm{m}$; on GYCA medium they formed shiny, slimy, convex and circular colonies with a diameter of 2 to $8 \mathrm{~mm}$, visible after $6 \mathrm{~d}$ of incubation; catalase; DNAase; peptonization in litmus milk; growth at initial pH 5.5 to 8.5 ; growth in the presence of $1 \%(\mathrm{w} / \mathrm{v}) \mathrm{NaCl}, 10 \%(\mathrm{w} / \mathrm{v}) \mathrm{D}$-glucose, $0.1 \%(\mathrm{w} / \mathrm{v})$ Actidione, $0.005 \%$ $(\mathrm{w} / \mathrm{v})$ triphenyltetrazolium chloride, $0.001 \%(\mathrm{w} / \mathrm{v})\left(\mathrm{NH}_{4}\right)_{2} \mathrm{CuCl}_{4} \cdot 2 \mathrm{H}_{2} \mathrm{O}, 0.01 \%$ (w/v) sodium salicylate, $0.01 \%(\mathrm{w} / \mathrm{v}) \mathrm{KIO}_{3}, 0.01 \%(\mathrm{w} / \mathrm{v}) \mathrm{KSCN}, 0.01 \%(\mathrm{w} / \mathrm{v})\left(\mathrm{NH}_{4}\right)_{6} \mathrm{Mo}_{7} \mathrm{O}_{24} \cdot 4 \mathrm{H}_{2} \mathrm{O}, 0.01 \%$ (w/v) $\left(\mathrm{NH}_{4}\right)_{2} \mathrm{~S}_{2} \mathrm{O}_{8}, 0.001 \%$ (w/v) $\mathrm{C}_{4} \mathrm{H}_{4} \mathrm{KO}_{7} \mathrm{Sb}, 0.001 \%$ (w/v) CuI, $0.0015 \%$ (w/v) $\mathrm{CuSO}_{4}$ $.5 \mathrm{H}_{2} \mathrm{O}, 0.012 \%(\mathrm{w} / \mathrm{v}) \mathrm{BaCl}_{2} .2 \mathrm{H}_{2} \mathrm{O}, 0.01 \%(\mathrm{w} / \mathrm{v}) \mathrm{Ba}\left(\mathrm{NO}_{3}\right)_{2}, 0.015 \%(\mathrm{w} / \mathrm{v}) \mathrm{MnCl}_{2} .4 \mathrm{H}_{2} \mathrm{O}$, $0.011 \%(\mathrm{w} / \mathrm{v}) \mathrm{MnSO}_{4} . \mathrm{H}_{2} \mathrm{O}, 0.01 \%(\mathrm{w} / \mathrm{v}) \mathrm{H}_{3} \mathrm{BO}_{3}, 0.01 \%(\mathrm{w} / \mathrm{v}) \mathrm{K}_{2} \mathrm{SO}_{4}, 0.01 \%(\mathrm{w} / \mathrm{v})$ methylene blue, $0.005 \%(\mathrm{w} / \mathrm{v})$ methyl green, $0.0001 \%(\mathrm{w} / \mathrm{v})$ crystal violet, $0.01 \%(\mathrm{w} / \mathrm{v})$ Nile blue, $0.01 \%$ $(\mathrm{w} / \mathrm{v})$ Bismarck brown and $0.01 \%$ (w/v) Congo red; growth on Pseudomonas $-\mathrm{F}$ agar; acid formation from D-fructose, D-galactose, sucrose; growth on D-glucose, D-mannose, trehalose, 


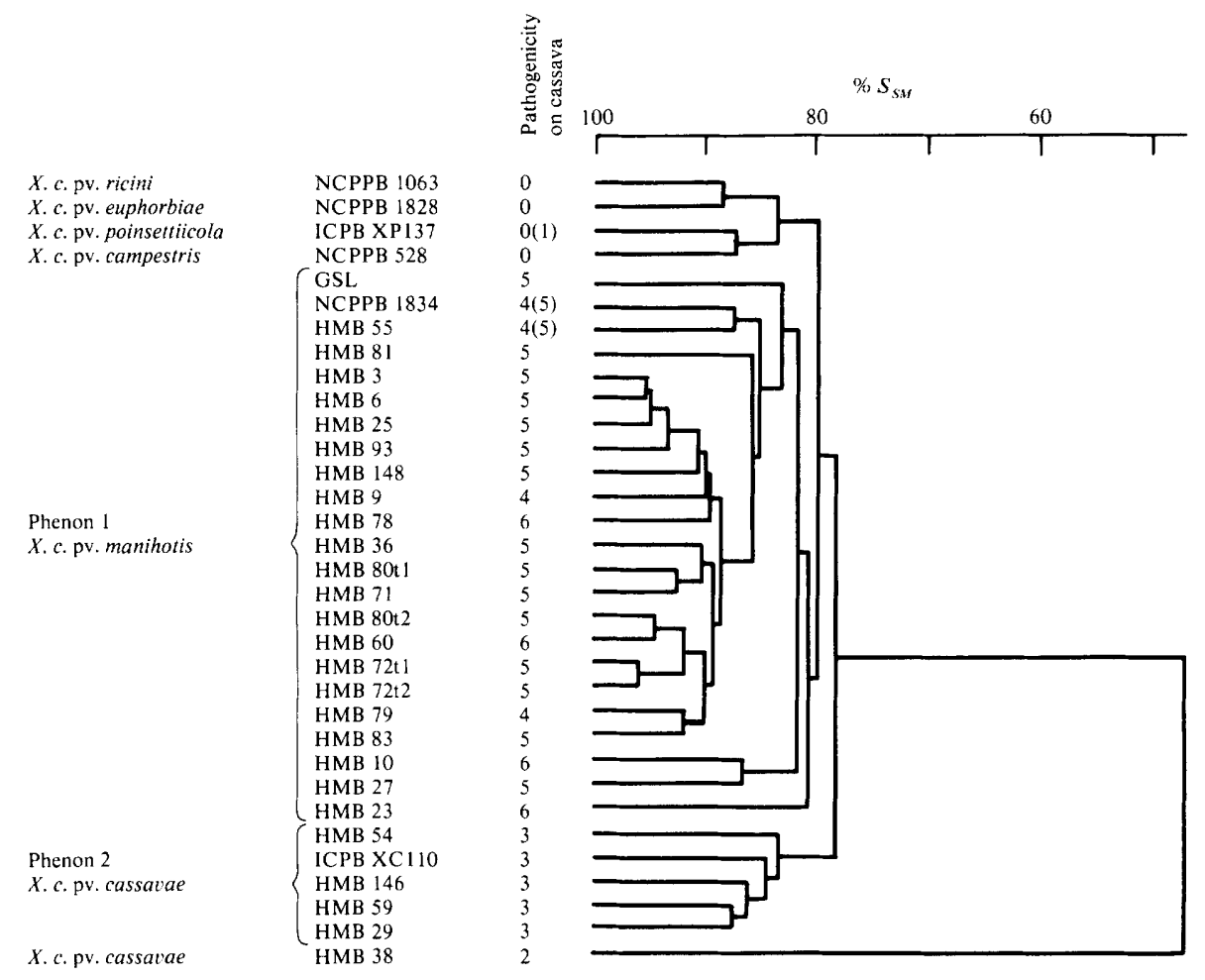

Fig. 1. Dendrogram obtained after numerical analysis of 267 phenotypic features of $32 X$. campestris $(X$. $c$.) strains isolated from cassava and some other Euphorbiaceae, and the type strain of $X$. campestris. The $S_{S M}$ coefficient and the unweighted average pair-group method were used. The pathogenicity on cassava is given on a 0 to 6 scale: $0-1$ is non-pathogenic and 6 is highly virulent.

cellobiose, D-fructose, trisodium citrate, sodium fumarate, sodium acetate, calcium gluconate, calcium lactate; the use of L-alanine as sole source of carbon and nitrogen; resistance towards $2 \mu \mathrm{g}$ lincomycin.

The following features were uniformly absent in the 33 strains: nitrate reduction; formation of indole and acetoin; fermentative utilization of D-glucose; production of a fluorescent pigment on Pseudomonas-F agar; anaerobic growth; acid formation in litmus milk; growth at $\mathrm{pH} 4.5$; growth at 4 or $37^{\circ} \mathrm{C}$; growth in the presence of $20 \%(\mathrm{w} / \mathrm{v}) \mathrm{D}$-glucose, $4 \%(\mathrm{w} / \mathrm{v}) \mathrm{NaCl}, 0.01 \%$ $(\mathrm{w} / \mathrm{v}) \mathrm{CuCl}_{2}, 0.01 \%(\mathrm{w} / \mathrm{v})$ cupric acetate, $0.02 \%(\mathrm{w} / \mathrm{v})$ cadmium acetate, $0.013 \%(\mathrm{w} / \mathrm{v})$ $\mathrm{Cu}\left(\mathrm{NO}_{3}\right)_{2} .3 \mathrm{H}_{2} \mathrm{O}, 0.015 \%$ (w/v) $\mathrm{CuSO}_{4} .5 \mathrm{H}_{2} \mathrm{O}, 0.018 \%$ (w/v) $\mathrm{CoSO}_{4} .7 \mathrm{H}_{2} \mathrm{O}, 0.01 \%$ (w/v) $\mathrm{CoCl}_{2}, 0.01 \%(\mathrm{w} / \mathrm{v}) \mathrm{ZnCl}_{2}, 0.07 \%$ (w/v) methyl green; acid formation from meso-erythritol, L-rhamnose, L-sorbose, sorbitol, salicin, adonitol, dulcitol and meso-inositol; growth on L-rhamnose, sodium 2-ketogluconate, salicin, inulin, glycolic acid, L-leucine, L-arginine, L-methionine, L-isoleucine, L-threonine, glycine, L-tryptophan, L-lysine, L-cysteine, ethanolamine, sodium hippurate, acetamide, n-butyrate, DL- $\beta$-hydroxybutyrate, pelargonate, ethanol, n-butanol, iso-butanol, diethyleneglycol, adonitol, sodium-potassium tartrate, sodium oxalate and sodium benzoate; utilization of L-asparagine, glycine or L-glutamine as sole source of carbon and nitrogen; resistance towards $10 \mu \mathrm{g}$ erythromycin, $10 \mu \mathrm{g}$ streptomycin or $30 \mu \mathrm{g}$ novobiocin.

Features giving different reactions are compiled in Table 2.

Only minor biochemical and physiological differences were noted between the two colony types ( $\mathrm{t} 1$ and $\mathrm{t} 2$; large and small colony diameter, respectively) of $X$. campestris $\mathrm{pv}$. manihotis strains HMB 72 and HMB 80 (Fig. 1); their protein patterns were almost identical (Fig. 2). 


\section{Table 2. Different phenotypic reactions for the strains of $X$. campestris pv. manihotis and pv. cassavae}

,$+ 90 \%$ or more of strains are positive $;-, 90 \%$ or more of strains are negative $; \mathrm{D}, 11-89 \%$ of strains are positive.

The following features occurred in more than $90 \%$ of the $X$. campestris pv. manihotis strains and in all pv. cassavae strains: acid formation from D-glucose, D-mannose and cellobiose; growth on sucrose, D-alanine, L-alanine, sodium succinate, sodium L-malate and sodium propionate; hydrolysis of starch; $\mathrm{H}_{2} \mathrm{~S}$ formation from L-cysteine; oxidative utilization of D-glucose; the use of sodium L-glutamate as sole $\mathrm{C}$ - and $\mathrm{N}$-source; tolerance of $10 \mu \mathrm{g}$ colistin sulphate.

The following features were absent in more than $90 \%$ of the $X$. campestris pv. manihotis strains and in all pv. cassavae strains: acid formation from D-ribose; utilization of $\mathrm{L}$-serine as sole $\mathrm{N}$-source; tolerance of $0.001 \%(\mathrm{w} / \mathrm{v})$ malachite green, $0.01 \%(\mathrm{w} / \mathrm{v})$ thionin, $30 \mu \mathrm{g}$ nalidixic acid, $30 \mu \mathrm{g}$ kanamycin, $10 \mu \mathrm{g}$ gentamycin, $10 \mu \mathrm{g}$ fusidic acid, $30 \mu \mathrm{g}$ chloramphenicol and $30 \mu \mathrm{g}$ tetracyclin.

The following features occurred in $11-89 \%$ of the $X$. campestris pv. manihotis strains and in one to five of the six pv. cassavae strains: cells in chains; occurrence of filaments, oxidase and polygalacturonase; tolerance of $2 \%(\mathrm{w} / \mathrm{v}) \mathrm{NaCl}$ and $0.01 \%(\mathrm{w} / \mathrm{v})$ triphenyltetrazolium chloride; acid from amygdalin; growth on glycerol; utilization of L-glycine, L-histidine and L-tyrosine as sole $\mathrm{N}$-source; tolerance of $0.001 \%(\mathrm{w} / \mathrm{v}) \mathrm{CuO}, 0.005 \%(\mathrm{w} / \mathrm{v})$ crystal violet, $0 \cdot 01 \%(\mathrm{w} / \mathrm{v})$ basic fuchsin, $100 \mu \mathrm{g}$ sulfafurazole, $10 \mathrm{U}$ penicillin $\mathrm{G}, 25 \mu \mathrm{g}$ cephaloridin, $10 \mu \mathrm{g}$ methicillin, $30 \mu \mathrm{g}$ neomycin, $200 \mu \mathrm{g}$ nitrofurantoin and $300 \mathrm{U}$ polymyxin $\mathbf{B}$.

\begin{tabular}{|c|c|c|c|}
\hline \multirow{3}{*}{ Phenotypic feature } & \multirow{3}{*}{ No. of strains } & \multicolumn{2}{|c|}{$X$. campestris pv. } \\
\hline & & manihotis & cassavae \\
\hline & & 23 & 6 \\
\hline ic acid & & - & + \\
\hline 60 ; growth on DL-glyceric acid & & + & - \\
\hline gelatinase, lecithinase and $\beta-g$ & from & + & $\mathrm{D}$ \\
\hline
\end{tabular}

Colonies yellow; growth on D-saccharic acid

Colonies white; hydrolysis of Tween 60 ; growth on DL-glyceric acid

Hydrolysis of Tween 80 and aesculin; gelatinase, lecithinase and $\beta$-glucosidase; acid f
melibiose and trehalose; growth on MG medium, D-galactose, melibiose, L-glutamic acid, $\mathrm{NH}_{4} \mathrm{Cl}+$ glucose, $\mathrm{NH}_{4} \mathrm{Cl}+$ glucose + minerals, $\mathrm{NH}_{4} \mathrm{Cl}+$ glucose + minerals + growth factors, $\mathrm{NH}_{4} \mathrm{Cl}+$ glucose + minerals + vitamin-free Casamino acids + vitamins, glucose + minerals + vitamins + vitamin-free Casamino acids; growth on $\mathrm{NH}_{4} \mathrm{Cl}+$ glucose + minerals + vitamins $+0.02 \%$ L-alanine, L-arginine, L-asparagine, L-cysteine, L-glutamic acid, L-glutamine, L-glycine, L-histidine, L-hydroxyproline, L-isoleucine, L-leucine, L-methionine, L-phenylalanine, L-proline, L-threonine, L-tyrosine, L-tryptophan, L-lysine or L-valine; utilization of L-alanine, L-arginine, L-asparagine, L-cysteine, L-glutamic acid, L-glutamine, L-hydroxyproline, L-isoleucine, L-leucine, L-methionine, L-phenylalanine, L-proline, L-threonine, L-tryptophan, L-lysine, L-valine or L-ornithine as sole $\mathrm{N}$-source; utilization of $\mathrm{L}$-hydroxyproline or proline as sole $\mathrm{C}$ - and $\mathrm{N}$-source; tolerance of $0.001 \% \mathrm{HgCl}_{2}, 0.001 \%$ $\mathrm{Hg}_{2}\left(\mathrm{NO}_{3}\right)_{2}, 0.001 \% \mathrm{Cu}_{2} \mathrm{Cl}_{2}, 0.005 \%$ safranin $\mathrm{T}, 0.005 \%$ methyl green, $0.0001 \%$ brilliant green

Coagulation in litmus milk; acid from lactose; growth on mucic acid

Alkalinization of litmus milk; growth on SX medium; acid from L-arabinose, maltose, D-xylose; growth on maltose; tolerance of $0.005 \%$ diamant fuchsin

Reduction in litmus milk; tolerance of $3 \% \mathrm{NaCl}$; acid from raffinose; tolerance of $0.001 \%$ cadmium acetate, $0.001 \%$ pyronin $\mathrm{Y}, 10 \mathrm{U}$ bacitracin or $10 \mu \mathrm{g}$ ampicillin

\section{Numerical comparison of protein gel electrophoregrams}

The protein electrophoregrams of 55 strains listed in Table 1 were prepared at least in duplicate. The reproducibility was excellent for the majority of the strains $(r>0.95)$. However, several $X$. campestris pv. cassavae strains showed, even after recultivation, reproducibility levels of $r=0.90$. The most typical electrophoregram of each strain (Swings et al., 1976) was used for the final clustering shown in Fig. 2. Meaningful taxonomic conclusions from numerical analyses of protein electrophoregrams can only be drawn above $r=0.85$ (Kersters, 1985); consequently, clustering levels below this value are represented as dashed lines in Fig. 2. Four electrophoretic clusters could be delineated at $r=0 \cdot 85$. All the $X$. campestris pv. manihotis strains grouped in the tight cluster 1 , whereas the $X$. campestris pv. cassavae strains grouped in two electrophoretic clusters, 2 and 3. The protein patterns of the yellow strains CIAT 1164 and CIAT 1165, isolated 
X.c. pv. ricini

$X$. c. pv. euphorbiae

$X . c$. pv. campestris

Cluster 1

X. c. pv, manihotis

Cluster 2

X. c. pv. cassavae

Cluster 3

X.c.pv. cassavae

Cluster 4

X.c. pv. poinsettiicola
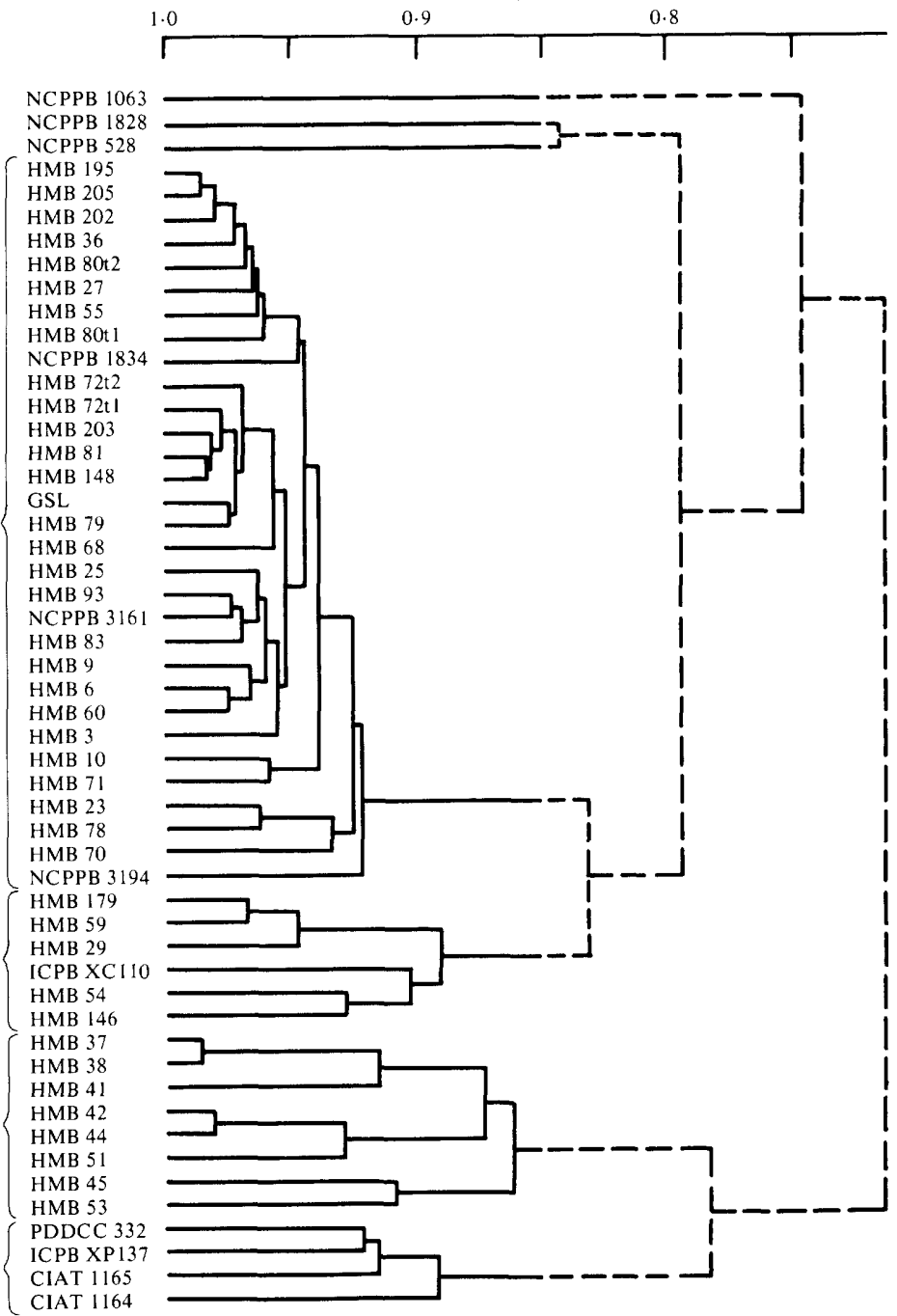

Fig. 2. Clustering of the protein electrophoregrams of $X$. campestris $(X . c$.) strains isolated from cassava and some other Euphorbiaceae, and the type strain of $X$. campestris, based on the correlation coefficient $r$ and the unweighted average pair-group method.

from cassava in Colombia (Elango et al., 1981), grouped in cluster 4 together with two strains of $X$. campestris pv. poinsettiicola. The type strain of $X$. campestris, NCPPB 528, and the neopathotype strains of $X$. campestris pv. euphorbiae and pv. ricini occupied a separate position in the dendrogram (Fig. 2). Protein electrophoregrams of 16 representative strains are shown in Fig. 3.

\section{DNA base composition and DNA : DNA hybridizations}

DNA was prepared from eight representative strains selected from the phenotypic and protein electrophoretic clusters. The mol $\% \mathrm{G}+\mathrm{C}$ values of the DNAs and the results of the DNA : DNA hybridizations are compiled in Table 3. Three DNA-hybridization groups were recognized. As expected from their phenotypic and protein electrophoretic similarities, $X$. campestris pv. manihotis strains NCPPB 1834 and HMB 25 were genetically highly related to each other ( $99 \%$ DNA-binding). A high degree of DNA-binding $(95 \%)$ was observed between 

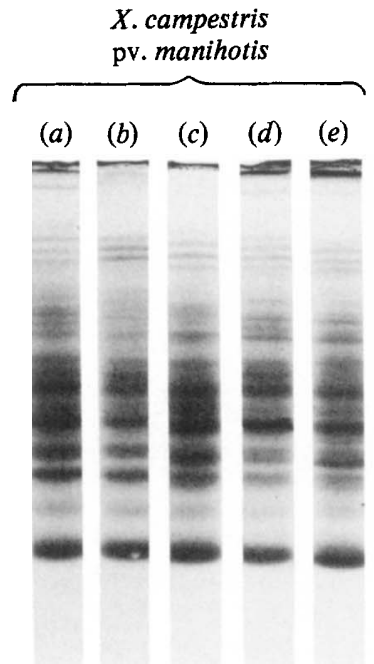
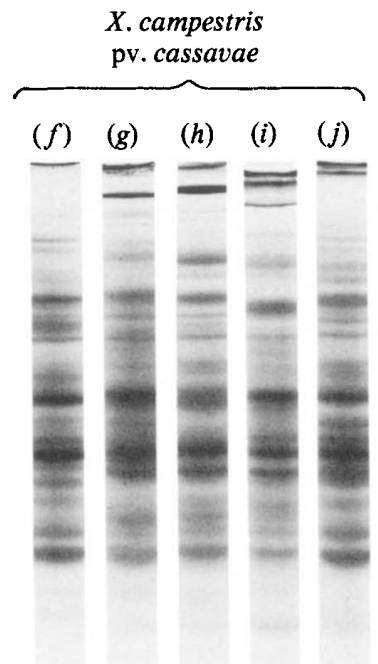

$X$. campestris pv. poinsettiicola

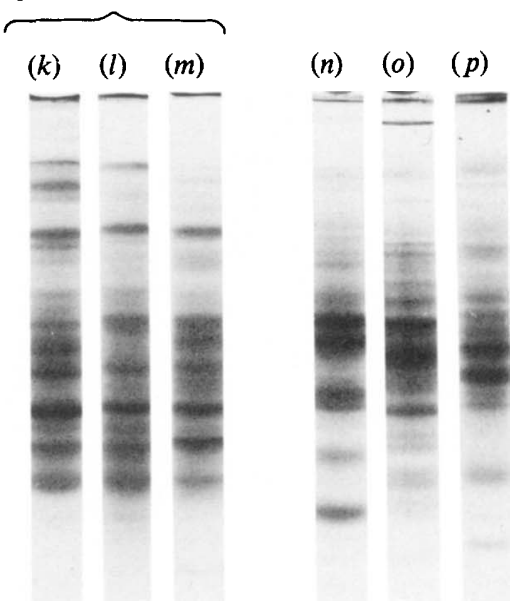

Fig. 3. Normalized protein electrophoregrams from $15 X$. campestris strains isolated from cassava and some other Euphorbiaceae. Lanes $(a)-(e): X$. campestris pv. manihotis HMB 25, HMB 71, NCPPB 1834, HMB 27, HMB 60. Lanes $(f)-(j): X$. campestris pv. cassavae HMB 54, HMB 146, HMB 38, HMB 44, HMB 51. Lanes $(k)$ and $(l)$ : yellowish isolates of Colombia CIAT 1164, CIAT 1165. Lane $(m)$ : $X$. campestris pv. poinsettiicola ICPB XP137. Lane $(n): X$. campestris pv, ricini NCPPB 1063. Lane $(o)$ : $X$. campestris pv. euphorbiae NCPPB 1828. Lane $(p): X$. campestris NCPPB 528.

Table 3. DNA:DNA hybridizations between representative strains from the different $X$. campestris clusters studied

The results are shown in a half matrix. The degree of DNA binding $(\% D)$ is expressed versus the homologous reaction.

\section{Strain}

1. X. campestris pv. manihotis NCPPB $1834^{*}$

2. X. campestris pv, manihotis $\mathrm{HMB} 25$

3. Yellowish isolate CIAT 1164

4. Yellowish isolate CIAT 1165

5. $X$. campestris pv. poinsettiicola ICPB XP137*

6. X. campestris pv. cassavae HMB $54^{*}$

7. $X$. campestris pv. cassavae HMB 38

8. X. campestris pv. campestris NCPPB $528 \dagger$

\begin{tabular}{|c|c|c|c|c|c|c|c|c|}
\hline \multirow{2}{*}{$\begin{array}{l}\mathrm{Mol} \% \\
\mathrm{G}+\mathrm{C}\end{array}$} & \multicolumn{8}{|c|}{ Degree of DNA binding: } \\
\hline & 1 & 2 & 3 & 4 & 5 & 6 & 7 & 8 \\
\hline 65.9 & 100 & & & & & & & \\
\hline- & 99 & 100 & & & & & & \\
\hline $66 \cdot 9$ & 60 & - & 100 & & & & & \\
\hline- & - & - & 98 & 100 & & & & \\
\hline $66 \cdot 4$ & 62 & 61 & 99 & - & 100 & & & \\
\hline $66 \cdot 2$ & 35 & - & 36 & - & $=$ & 100 & & \\
\hline - & - & - & - & - & - & 95 & 100 & \\
\hline $65 \cdot 2 \ddagger$ & 18 & - & 37 & - & - & 34 & - & 100 \\
\hline
\end{tabular}

\footnotetext{
-, Not determined.

* Neopathotype strain.

† Type strain.

‡ From De Vos \& De Ley (1983).
}

$X$. campestris pv. cassavae HMB 54 (neopathotype strain; member of phenon 2 and electrophoretic cluster 2) and $X$. campestris pv. cassavae HMB 38, which belonged to electrophoretic cluster 3 (Fig. 2) and occupied a separate position in the phenogram (Fig. 1). The DNA-relatedness between $X$. campestris pv. manihotis and pv. cassavae was low (35\% DNAbinding; Table 3). The yellow cassava isolates from Colombia (strains CIAT 1164 and CIAT 1165) were genetically highly related to each other and to the neopathotype strain of $X$. campestris pv. poinsettiicola, ICPB XP137, reflecting the protein electrophoretic similarities of 
these strains. They have a higher DNA : DNA homology $(60 \% D)$ with the $X$. campestris pv. manihotis cluster than with the $X$. campestris pv. cassavae cluster $(36 \% D)$ and the type strain of $X$. campestris pv. campestris $(37 \% D)$.

\section{Pathogenicity}

On cassava leaves, all the pv. manihotis strains induced angular leaf spots evolving into blight areas, and caused a systemic infection in the stem leading to formation of bacterial pockets, followed by exudation, wilting and abscission of the leaves (Table 1). Differences in the speed of symptom formation were evident: strains HMB 10, HMB 23, HMB 60 and HMB 78 were the most virulent ones, whereas strains HMB 9, HMB 68 and HMB 79 were weakly virulent. The neopathotype strain NCPPB 1834, a subculture of the original isolate (ENA-300) reported as inducing only necrotic angular leaf spots (Robbs et al., 1972), showed a low to intermediate virulence that was different from the pv. cassavae strains. $X$. campestris pv. cassavae strain HMB 38 showed a lower virulence than the other pv. cassavae strains.

The Colombian yellowish isolates occasionally induced small spots, which rapidly became necrotic, on the leaves and a restricted browning of the vessels. Similar restricted lesions were induced on cassava by pv. poinsettiicola, but not by pv. euphorbiae, pv. ricini, nor pv. campestris.

On E. pulcherrima, restricted lesions were observed after inoculation with all strains tested except pv. poinsettiicola and pv. ricini, which induced water-soaked greasy spots extending more than $4 \mathrm{~mm}$ around the inoculation point (Table 4 ). On $R$. communis, only pv. ricini induced this type of symptom, the other strains causing no reaction.

\section{DISCUSSION}

All strains of phenons 1 and 2 possessed both the generic characteristics of Xanthomonas and all the features described for the species X. campestris (Bradbury, 1984; Van den Mooter, 1984). The $\mathrm{mol} \% \mathrm{G}+\mathrm{C}$ of representative strains of $X$. campestris pv. manihotis and pv. cassavae (Table 3 ) fit in the mol $\% \mathrm{G}+\mathrm{C}$ range of $X$. campestris (63.5-69.2\%; Bradbury, 1984). The generic assignment of $X$. campestris pv. manihotis HMB 25 and pv. cassavae HMB 38 to the genus Xanthomonas was also confirmed by DNA : rRNA hybridizations using ${ }^{14} \mathrm{C}$-labelled rRNA of the type strain $X$. campestris NCPPB 528 (P. Segers \& J. De Ley, unpublished results).

A good overall correlation was found between the grouping obtained by numerical analysis of phenotypic features, protein electrophoregrams and DNA:DNA hybridizations. All $X$. campestris pv. manihotis strains clustered in the homogeneous phenon 1 (Fig. 1) and the tight electrophoretic cluster 1 (Fig. 2). All the $X$. campestris pv. cassavae strains of phenon 2 (Fig. 1) grouped in electrophoretic cluster 2, whereas the phenotypically aberrant strain HMB 38 grouped with seven other $X$. campestris pv. cassavae strains in the protein electrophoretic cluster 3 (Fig. 2). Yet, strain HMB 38 has $95 \%$ DNA homology (Table 3) with strain HMB 54 (the neopathotype strain of $X$. campestris pv. cassavae), and is thus considered to be an authentic member of this pathovar (Table 2).

\section{$X$. campestris pv. manihotis (phenon 1, electrophoretic cluster I)}

In addition to the features of $X$. campestris already described by Bradbury (1984), the following characteristics were detected in more than $90 \%$ of the X.campestris pv. manihotis strains: hydrolysis of Tween 60, Tween 80 and starch; growth in the presence of $0.001 \%(\mathrm{w} / \mathrm{v})$ $\mathrm{Hg}\left(\mathrm{NO}_{3}\right)_{2}$ but not in the presence of $0.05 \%(\mathrm{w} / \mathrm{v})$ triphenyltetrazolium chloride or $0.001 \%(\mathrm{w} / \mathrm{v})$ malachite green; $\beta$-glucosidase activity; acid formation from melibiose but not from D-ribose and lactose; growth on DL-glyceric acid but not on mucic acid, saccharic acid or ethanol; use of $\mathrm{L}$-threonine as sole source of nitrogen and susceptibility against $10 \mu \mathrm{g}$ gentamycin and $10 \mu \mathrm{g}$ fusidic acid. None of the $X$. campestris pv. manihotis strains produces a yellow pigment.

Biochemical and physiological variations within this pathovar have already been mentioned by Maraite et al. (1981). No correlation was found between biochemical and physiological features or a group of features and protein electrophoretic patterns on the one hand and the geographical origin, year of isolation or virulence on the other. Highly virulent and weakly 


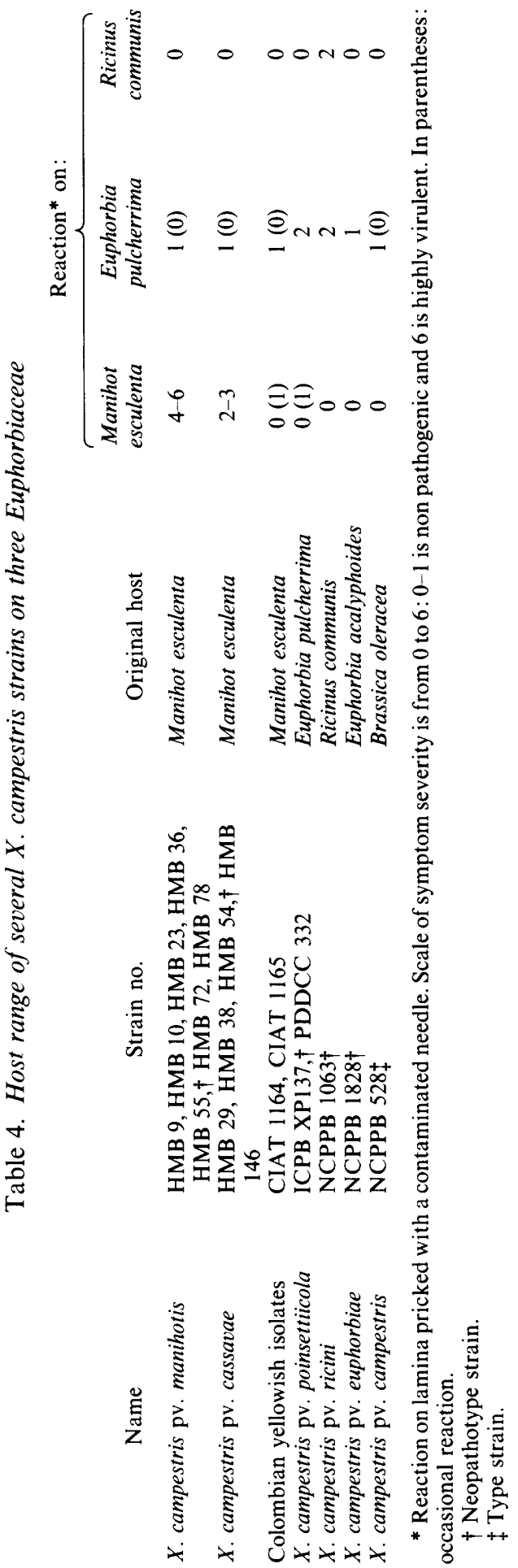


virulent strains were situated at random in the dendrograms (Figs 1 and 2). A similar situation has also been observed within X. oryzae and X. campestris pv. oryzicola (Vera Cruz et al., 1984; Van den Mooter, 1984) and $X$. graminis, $X$. campestris pv. phlei, pv. arrhenatheri and pv. poae (Van den Mooter, 1984; Van den Mooter et al., 1986).

The strains HMB 10, HMB 23 and HMB 27 grouped in the phenogram (Fig. 1) somewhat separate from the other $X$. campestris pv. manihotis strains, but were scattered over the electrophoretic cluster 1 (Fig. 2). Upon visual inspection, the protein patterns of these three strains were almost identical to those of the other pv. manihotis strains. The high degree of genetic relatedness between strains NCPPB 1834 and HMB 25 (Table 3) consolidates the phenotypic and protein electrophoretic similarities of the investigated $X$. campestris $\mathrm{pv}$. manihotis strains. All our data indicate that the pv. manihotis strains constitute a phenotypically and genetically homogeneous group of bacteria, clearly distinct from $X$. campestris pv. cassavae.

\section{$X$. campestris pv. cassavae (phenon 2, electrophoretic clusters 2 and 3)}

In addition to the features of the species $X$. campestris already described by Bradbury (1984), the following characteristics were found in all the strains of $X$. campestris pv. cassavae: yellow pigmentation; hydrolysis of starch; lack of growth in the presence of $0.05 \%(\mathrm{w} / \mathrm{v})$ triphenyltetrazolium chloride, $0.001 \%(\mathrm{w} / \mathrm{v})$ pyronin $\mathrm{Y}$ or $0.001 \%(\mathrm{w} / \mathrm{v})$ malachite green; growth on SX agar; acid formation from maltose or xylose but not from raffinose or ribose; growth on maltose, saccharic acid but not on DL-glyceric acid and ethanol; susceptibility to $10 \mathrm{U}$ bacitracin.

Phenotypically (Fig. 1) and when compared by protein electrophoresis (Fig. 2), X. campestris pv. cassavae was more heterogeneous than $X$. campestris pv. manihotis. Although the protein patterns of the pv. cassavae strains were similar (Fig. 3), two electrophoretic clusters were delineated by numerical analysis (Fig. 2). Only strain HMB 38 of electrophoretic cluster 3 was investigated in the phenotypic analysis; it occupied a separate position in the phenogram (Fig. 1). This strain differed from the other pv. cassavae strains by its inabililty to utilize amino acids as sole source of nitrogen and by its lower virulence, yet it showed a high degree of DNArelatedness with the neopathotype strain HMB 54. Within the pathovar cassavae no correlation was detected between the phenotypic features and the protein electrophoretic patterns on the one hand and the geographical origin, year of isolation or pathogenicity on the other.

\section{Differentiation of $X$. campestris $p v$. manihotis from pv. cassavae}

A clearcut differentiation between the pathovars manihotis (phenon 1) and cassavae (phenon 2 and strain HMB 38) is possible by growth on saccharic acid, growth on DL-glyceric acid, hydrolysis of Tween 60 and the formation of yellow pigment (pv. manihotis gives negative, positive, positive and negative results, and pv. cassavae the opposite) (Table 2). Until now, the only differential character between the pathovars manihotis (white) and cassavae (yellow) was pigmentation (Maraite \& Weyns, 1979). It should be noted, however, that the absence of the typical yellow pigment is not limited to the pathovar manihotis; e.g. some strains belonging to the pathovars phyllanthi, ricini, vitiswoodrowii, vesicatoria, mangiferaeindicae, azadirachtae and pedalii and to Xanthomonas maltophilia are also white (Van den Mooter, 1984). Maraite \& Weyns (1979) differentiated the pathovars manihotis and cassavae by the acidification of maltose: the former showing a delayed (5-16 d) and the latter a rapid ( $2 \mathrm{~d}$ ) acidification. In the present work, $X$. campestris pv. manihotis strains showed differences in acid production from maltose (see Table 2). Growth on different carbon sources has not received much attention in previous publications. From our results it is obvious that growth on saccharic acid and glyceric acid are useful features to differentiate the two pathovars. No differences were found between the two phenons in the susceptibility towards antibiotics in vitro. The susceptibility patterns agree with those found for the strains of the species X. campestris (Van den Mooter et al., 1981).

\section{$X$. campestris pv. poinsettiicola and the yellowish strains isolated from cassava in Colombia (electrophoretic cluster 4)}

Elango et al. (1981) found that the yellow strains, isolated from cassava in Colombia were 
serologically similar to $X$. campestris pv. cassavae. However, our results show that the two Colombian strains CIAT 1164 and CIAT 1165 were electrophoretically different from the pv. cassavae strains, but very similar to the investigated $X$. campestris pv. poinsettiicola strains (Figs 2 and 3). DNA :DNA hybridizations (Table 3) confirmed that the Colombian cassava isolate CIAT 1164 is genetically highly related to the neopathotype strain of $X$. campestris $\mathrm{pv}$. poinsettiicola ICPB XP137 (99\% DNA-binding) and clearly different from $X$. campestris pv. cassavae HMB 54. The ability of $X$. campestris pv. poinsettiicola ICPB XP137 to induce active lesions on E. pulcherrima differentiated it, however, from the non-pathogenic or only weakly pathogenic Colombian yellowish isolates (Table 4). The reported overlap in host-range of pv. poinsettiicola (infecting E. pulcherrima and $M$. esculenta) and pv. euphorbiae (infecting $E$. acalyphoides and $R$. communis) (Sabet et al., 1969) was not confirmed by our results. However, $X$. campestris pv. ricini NCPPB 1063 and other pv. ricini strains (H. Maraite \& N. de Bonhome, unpublished data) induced active lesions on E. pulcherrima, similar to those caused by pv. poinsettiicola. DNA-binding values (Table 3) indicate that the yellowish Colombian isolates and pv. poinsettiicola strain ICPB XP137 are genetically more closely related to pv. manihotis $(60 \%$ $D$ ) than to strains of $X$. campestris pv. cassavae $(36 \% D)$. On the basis of the protein profiles of the outer cell membranes, Dos Santos \& Dianese (1985) also concluded that the Colombian yellowish isolates are more related to pv. manihotis than to pv. cassavae. Based on the analysis of the soluble enzymes, Kimura \& Dianese (1983) even suggested that the Colombian isolates could be yellow strains of pv, manihotis; but our data demonstrate clear differences between these strains and pv. manihotis.

The rather low DNA-relatedness values, the phenotypic features, the protein electrophoregrams and phytopathogenic symptoms allow a clearcut differentiation between $X$. campestris pv. cassavae, pv. manihotis and pv. poinsettiicola. More $X$. campestris strains isolated from other Euphorbiaceae need to be compared before definite conclusions can be drawn concerning the relationships of pv. manihotis, pv. cassavae and pv. poinsettiicola versus pv. euphorbiae, pv. phyllanthi and pv. ricini.

J.D.L. is indebted to the Fonds voor Geneeskundig Wetenschappelijk Onderzoek and to the Instituut tot Aanmoediging van het Wetenschappelijk Onderzoek in Nijverheid en Landbouw (IWONL) (Belgium) for research and personnel grants. H.M. is grateful to the International Institute of Tropical Agriculture, Ibadan, Nigeria, and the Administration de la Coopération au Développement, Brussels, for collaboration and funding, and to Nadine de Bonhome for technical assistance. K.K. and J.S. are grateful to the Nationaal Fonds voor Wetenschappelijk Onderzoek for research grants. M.V.d.M. is indebted to the IWONL for scholarships.

\section{REFERENCES}

BARRITT, M. M. (1936). The intensification of VogesProskauer reaction by the addition of $\alpha$-naphthol. Journal of Pathological Bacteriology 42, 441-454.

Bauer, A. W., Kirby, W. M. M., Sherris, J. C. \& TURCK, M. (1966). Antibiotic susceptibility testing by a standardized single disk method. American Journal of Clinical Pathology 45, 493-496.

Bonham-CARTER, G. F. (1967). Fortran IV Program for $Q$-mode Cluster Analysis of Nonquantitative Data using IBM 7090/7094 Computers. Kansas Geological Survey Computer Program. Lawrence, USA: The University of Kansas.

Bradbury, J. F. (1984). Genus II. Xanthomonas Dowson 1939, 187. In Bergey's Manual of Systematic Bacteriology, pp. 199-210. Edited by N. R. Krieg. Baltimore: Williams \& Wilkins.

DE LEY, J. (1970). Reexamination of the association between melting point, buoyant density, and chemical base composition of deoxyribonucleic acid. Journal of Bacteriology 101, 738-754.

DE Ley, J. \& VAN MuYlem, J. (1963). Some applications of deoxyribonucleic acid base compo- sition in bacterial taxonomy. Antonie van Leeuwenhoek 29, 344-358.

De Ley, J., Cattoir, H. \& Reynaerts, A. (1970). The quantitative measurement of DNA hybridization from renaturation rates. European Journal of Biochemistry 12, 133-142.

DE VOS, P. \& DE LEY, J. (1983). Intra- and intergeneric similarities of Pseudomonas and Xanthomonas ribosomal ribonucleic acid cistrons. International Journal of Systematic Bacteriology 33, 487-509.

DOETSCH, R. N. (1981). Determinative methods of light microscopy. In Manual of Methods for General Bacteriology, pp. 21-33. Edited by P. Gerhardt, R. G. E. Murray, R. N. Costilow, E. W. Nester, W. A. Wood, N. R. Krieg, \& G. B. Phillips. Washington, DC: American Society for Microbiology.

Dos Santos, R. M. D. B. \& Dianese, J. C. (1985). Comparative membrane characterization of Xanthomonas campestris pv. cassavae and $X$. campestris pv. manihotis. Phytopathology 75, 581-587.

Dowson, W. J. (1939). On the systematic position and 
generic names of the Gram negative bacterial plant pathogens. Zentralblatt für Bakteriologie, Parasitenkunde, Infektionskrankheiten und Hygiene (Abteilung II) 100, 177-193.

DYE, D. W. (1962). The inadequacy of the usual determinative tests for the identification of Xanthomonas spp. New Zealand Journal of Science 5, 393416.

Dye, D. W., Bradbury, J. F., Goto, M., Hayward, A. C., Lelliott, R. A. \& Schroth, M. N. (1980). International standards for naming pathovars of phytopathogenic bacteria and a list of pathovar names and pathotype strains. Review of Plant Pathology 59, 153-168.

Elango, F. N., Lozano, J. C. \& Peterson, J. F. (1981). Relationships between Xanthomonas c. pv. manihotis, X.c. pv. cassavae and Colombian yellowish isolates. Proceedings of the Fifth International Conference on Plant Pathogenic Bacteria, pp. 96-104. Cali, Colombia: CIAT.

KeRSters, K. (1985). Numerical methods in the classification of bacteria by protein electrophoresis. In Computer-assisted Bacterial Systematics (Special Publication of the Society for General Microbiology), pp. 337-368. Edited by M. Goodfellow, D. Jones \& F. G. Priest. London: Academic Press.

KERSTERS, K. \& DE LEY, J. (1975). Identification and grouping of bacteria by numerical analysis of their electrophoretic protein patterns. Journal of General Microbiology 87, 333-342.

Kimura, O. \& Dianese, J. C. (1983). Caracterização proteica e isoenzimática dos patovares de $X$. campestris (Pammel) Dowson que atacam a mandioca. Pesquisa Agropecuaria Brasileira 18, 12151228.

Kovacs, N. (1928). Eine vereinfachte Methode zum Nachweis der Indolbildung durch Bakterien. Zeitschrift für Immunitätsforschung und experimentelle Therapie 55, 311-315.

Kovacs, N. (1956). Identification of Pseudomonas pyocyanea by the oxidase reaction. Nature, London 178, 703.

Maraite, H. \& Perreaux, D. (1979). Comparative symptom development in cassava after infection by Xanthomonas manihotis or $X$. cassavae under controlled conditions. In Cassava Bacterial Blight in Africa. Past, Present and Future, pp. 17-24. Edited by E. Terry, G. Persley \& S. Cook. London: COPR.

Maraite, H. \& Weyns, J. (1979). Distinctive physiological, biochemical and pathogenic characteristics of Xanthomonas manihotis and X. cassavae. In Diseases of Tropical Food Crops, pp. 103-117. Edited by H. Maraite \& J. A. Meyer. Louvain-la-Neuve, Belgium: Université Catholique de Louvain.

Maraite, H., Weyns, J., Yimkwan, O., Lipemba, P. \& Perreaux, D. (1981). Physiological and pathogenic variations in Xanthomonas campestris pv. manihotis. Proceedings of the Fifth International Conference on Plant Pathogenic Bacteria, pp. 358-368. Cali, Colombia: CIAT.

MARMUR, J. (1961). A procedure for the isolation of deoxyribonucleic acid from micro-organisms. Journal of Molecular Biology 3, 208-218.

MARMUR, J. \& DotY, P. (1962). Determination of the base composition of deoxyribonucleic acid from its thermal denaturation temperature. Journal of Molecular Biology 5, 109-118.

Pammel, L. H. (1895). Bacteriosis of rutabaga, (Bacillus campestris n. sp.). Iowa State College Agricultural Experimental Station Bulletin 27, 130-134.

Paton, A. M. (1959). An improved method for preparing pectate gels. Nature, London 183, 18121813.

Robbs, C. F., Ribeiro, R., Kimura, O. \& Akiba, F. (1972). Variações en Xanthomonas manihotis (Arthaud-Berthet) Starr. Revista da Sociedade Brasileira de Fitopatologia 5, 67-75.

Sabet, K. A., IshaG, F. \& Khalil, O. (1969). Studies on the bacterial diseases of Sudan crops. VII. New records. Annals of Applied Biology 63, 357-369.

SCHAAD, N. W. (editor) (1980). Laboratory Guide for Identification of Plant Pathogenic Bacteria. St Paul, Minn., USA : Bacteriological Committee of American Phytopathological Society.

SNeATH, P. H. A. \& SoKal, R. R. (1973). Numerical Taxonomy. The Principles and Practice of Numerical Classification. San Francisco: W. H. Freeman.

SoKal, R. R. \& Michener, C. D. (1958). A statistical method for evaluating systematic relationships. University of Kansas Scientific Bulletin 38, 1409-1438.

STARR, M. P. (1945). The nutrition of phytopathogenic bacteria. I. Minimal nutritive requirements of the genus Xanthomonas. Journal of Bacteriology 51, 131143.

Swings, J., Kersters, K. \& De Ley, J. (1976). Numerical analysis of electrophoretic protein patterns of Zymomonas strains. Journal of General Microbiology 93, 266-271.

Van den Mooter, M., Swings, J., De Cleene, M., LEYNS, F. \& DE LEY, J. (1981). Sensitivity of Xanthomonas towards antibiotics in vitro. Mededelingen van de Faculteir Landbouwwetenschappen Rijksuniversiteit Gent 46, 787-792.

VAN DEN MOOTER, M. (1984). De taxonomie van het plantpathogene bakteriëngeslacht Xanthomonas Dowson 1939. PhD thesis, Rijksuniversiteit Gent, Belgium.

Van Den Mooter, M., Steenackers, M., Maertens, C., Gossele, F., De Vos, P., Swings, J., Kersters, K. \& DE LEY, J. (1986). Differentiation between Xanthomonas campestris pv. graminis (ISPP List 1980), pv. phleipratensis (ISPP List 1980) emend., pv. poae Egli and Schmidt 1982 and pv. arrhenatheri Egli and Schmidt 1982, by numerical analysis of phenotypic features and protein gel electrophoregrams. Phytopathologische Zeitschrift (in the Press).

Vera Cruz, C. M., Gossele, F., Kersters, K., Segers, P., VAN DEN MoOter, M., Swings, J. \& DE LEY, J. (1984). Differentiation between Xanthomonas campestris pv. oryzae, Xanthomonas campestris pv. oryzicola and the bacterial 'brown blotch' pathogen on rice by numerical analysis of phenotypic features and protein gel electrophoregrams. Journal of General Microbiology 130, 2983-2999.

WisharT, D. (1978). Clustan User Manual, Version IC, Release 2, 3rd edn. Edinburgh: Program Library Unit, Edinburgh University. 